\title{
Cytotoxic Effect of Selected Wild Medicinal Plant Species from Jordan on Two Different Breast Cancer Cell Lines, MCF7 and T47D
}

\author{
Israa Yousef $^{1}$, Sawan Oran ${ }^{1 *}$, Yasser Bustanji ${ }^{2}$, Dawud Al-Eisawi ${ }^{1}$ and Bashaer Abu-Irmaileh ${ }^{3}$ \\ ${ }^{1}$ Department of Biological Sciences, School of Science, The University of Jordan, Amman, Jordan \\ ${ }^{2}$ School of Pharmacy, The University of Jordan, Amman, Jordan \\ ${ }^{3}$ Hamdi Mango Center for Academic Research, The University of Jordan, Amman, Jordan
}

*Corresponding author: Sawan Oran, Department of Biological Sciences, School of Science, The University of Jordan, Amman, Jordan, Tel: +962-6-5322226 E-mail: oransaw@ju.edu.jo

Received date: May 30, 2018; Accepted date: July 06, 2018; Published date: July 13, 2018

Copyright: $\odot 2018$ Yousef $\mathrm{I}$, et al. This is an open-access article distributed under the terms of the Creative Commons Attribution License, which permits unrestricted use, distribution and reproduction in any medium, provided the original author and source are credited.

\begin{abstract}
Background: Breast cancer is the most common type of cancer in females in Jordan, it accounts for about $35.3 \%$ of all female cancers. Searching for alternative medicine from plants for breast cancer is a paramount importance. No studies have investigated the cytotoxic effect of the plants of Ajuga chia, Micromeria nervosa and Origanum dayi that are belonging to the family Lamiaceae and are growing wild in Jordan.
\end{abstract}

Objective: To investigate the cytotoxic effect of the A. chia, M. nervosa and O. dayi plant species against two different breast cancer cell lines MCF7 and T47D.

Materials and methods: The aerial parts of the aforementioned plant species were extracted with water and ethanol. Cell viability was assessed using MTT assay, after incubation with various concentrations of plant extracts.

Results: A pronounced cytotoxic effect of the ethanolic extract of $O$. dayi against MCF7 and T47D cell lines, with $\mathrm{IC}_{50}=99.4 \pm 2.9$ and $250 \pm 4 \mu \mathrm{g} / \mathrm{mL}$ respectively. The ethanolic extract of $A$. chia has shown cytotoxic effect against T47D cell line with $I C_{50}=200 \pm 5.2$. The aqueous and ethanolic extracts of $M$. nervosa did not show any toxicity against the aforementioned cell lines. The three plant species showed selectivity when they were tested on fibroblasts (normal cells).

Conclusion: Origanum dayi exhibited good cytotoxicity against aforementioned cell lines among the detected plant species, so $O$. dayi is considered a candidate for the development of a novel agent against breast cancer.

Keywords: Cytotoxicity; Breast cancer; Ajuga chia; Origanum dayi; Micromeria nervosa

\section{Introduction}

Using medicinal plants for healing by man is an old practice. In the past time, man searches for drugs from different sources such as preserved monuments, writer documents, and from plants [1]. Since early times, plants were playing an important and key role in food and drug administration [2].

Medicinal plants are considered as a healthy source of human life because of their therapeutically capacities in treatment of different diseases [3]. The therapeutically capacities of a medicinal plant depends on its ingredients such as alkaloids, cardiac glycosides, saponins, flavonoids, tannins, volatile oil, steroids, terpenoids, resin, and mucilage. Plants are exposed to phytochemical screening technique for the detection of their different ingredients that they have [4].

Medicinal plants occupied 20\% of the total flora of Jordan. These plants could be used in pharmaceutical industry and actually used in traditional medicine [2]. Ethnobotany is the survey of interaction between plants and people, emphasizing on traditional culture [6]. The use of medicinal plants by Jordanian people and the diversity of these plants have been recorded $[5,6]$. In Jordan, breast cancer is the most common type of cancer in female and accounts for about $35.3 \%$ of all female cancers. Unlike western countries, colorectal cancer is the leading type of cancer in Jordanian males and accounts for about $14.5 \%$ of all types of male cancers [7,8]. A study has been carried out on a breast cancer in Jordan according to univariate test (age, stage and others), the study indicated that the stage of tumor is a key factor that affected the survival of the cancer patient [9]. The plants $A$. chia, $M$. nervosa and $O$. dayi are belonging to Lamiaceae family and growing wild in Jordan. The aim of this present study is to investigate the in vitro cytotoxic activity of these plants on human breast cancer cell lines (MCF7 and T47D).

\section{Materials and Methods}

\section{Plant materials}

The aerial parts of plant species: Ajuga chi, Micromeria nervosa and Origanum dayi were collected from Amman and Al-karak-areas in Jordan- during summer, winter and spring (2016-2017) and completely dried. The plant species have been authentically identified by Prof. Sawsan Oran (Department of Biological Sciences, University of 
Citation: Yousef I, Oran S, Bustanji Y, Al-Eisawi D, Abu-Irmaileh B (2018) Cytotoxic Effect of Selected Wild Medicinal Plant Species from Jordan on Two Different Breast Cancer Cell Lines, MCF7 and T47D. Biol Med (Aligarh) 10: 443. doi:10.4172/0974-8369.1000443

Page 2 of 4

Jordan). Voucher specimens of collected plants are deposited at The Herbarium, Department of Biological Sciences, University of Jordan.

\section{Preparation of plant extracts}

Collected aerial parts of all plants were air dried for approximately three weeks at room temperature $\left(23-27^{\circ} \mathrm{C}\right)$. Dried plant materials were powdered using an electrical blender. $60 \mathrm{gm}$ of each dried powdered plant material was dissolved separately in $600 \mathrm{ml}$ of distilled water/absolute ethanol (Solvent to sample ratio of 10:1 (v/w) solvent to dry weight ratio) by using a reflux for 72 hours with $60^{\circ} \mathrm{C}$ (Ling, et al. 2016). The extractions were then filtered through Whitman no. 1 filter papers. The filtrates were concentrated (evaporated of solvents) by using rotary evaporator at $60^{\circ} \mathrm{C}$ and subsequently left to completely dry. Plant extracts were dissolved in DMSO.

\section{Cell culture}

Human cancer cell lines were used to evaluate the cytotoxic effect of different plant extracts. Cancer cell lines selected from the 60 cell lines, screened by the US National Cancer Institute (NCI) which includes: MCF-7 and T47D Cell lines. Cell lines were taken out of the liquid nitrogen and were rapidly thawed in a $37^{\circ} \mathrm{C}$ water bath before use. The outer surface of the vials was then disinfected with $70 \%$ ethanol and its contents were gently added to a prewarmed $\left(37^{\circ} \mathrm{C}\right)$ Modified Eagle Medium (DMEM) in $15 \mathrm{~mL}$ centrifuge tube under sterile conditions. Cells were washed with the medium at room temperature. Cells were cultured in DMEM, supplemented with $10 \%$ heat inactivated fetal bovine serum (FBS), $20 \mu \mathrm{M}$ L-glutamine, $50 \mathrm{IU} / \mathrm{mL}$ penicillin, and 50 $\mu \mathrm{g} / \mathrm{mL}$ streptomycin. Cells were maintained in incubator at $37^{\circ} \mathrm{C}$ in a $5 \% \mathrm{CO}_{2}$ atmosphere with $95 \%$ humidity and then harvesting with trypsin-EDTA solution.

\section{Seeding of MCF7 and T47D cell lines}

Confluent flasks of different cell lines were used for preparing the seeding of these cells in 96 well plates. The flasks $\left(25\right.$ and $\left.75 \mathrm{~cm}^{2}\right)$ were washed with $3 \mathrm{~mL} / 6 \mathrm{~mL}$ of PBS, and then $1 \mathrm{~mL} / 2 \mathrm{~mL}$ of trypsin/EDTA was added respectively and the flasks were incubated for 5-10 min at $37^{\circ} \mathrm{C}$. The fresh media was added $(3 \mathrm{~mL} / 6 \mathrm{~mL})$ to the 25 and $75 \mathrm{~cm}^{2}$ respectively. Cell suspension then transferred to sterile tube in order to pull $25 \mu \mathrm{L}$ from it into eppendorf tube that contains $25 \mu \mathrm{L}$ trypan blue dye, to count the number of cells that found in the suspension by using hemocytometer according to the following formula: (Number of cells=average number of cells from each of the sets of 16 corner squares of hemocytometer $\times 2$ (dilution factor) $\times 10000 \times$ volume of cell suspension). From the cell suspension, an appropriate volume was withdrawn and the volume was completed with fresh medium to end up with a final required cell density. Using multichannel pipette, 100 $\mu \mathrm{L}$ of cell suspension were seeded per well in 96-well plates and incubated to allow for cell attachment. $1 \times 10^{4}$ cells $/ \mathrm{mL}$ were either left untreated (culture in growth medium alone) or stimulated with 200 , $100,50,25,12.5$ and $6.25 \mu \mathrm{g} / \mathrm{mL}$ of the seven plant extracts separately in growth medium for $72 \mathrm{~h}$. Treated cells were incubated in a $37^{\circ} \mathrm{C}$.

\section{Cell viability assay (MTT)}

MTT (3-(4,5-dimethyl-thiazol-2-yl)-2,5-diphenyltetrazolium bromide) assay (Sigma) was used for assessing cell viability after incubation with various concentrations of plant extracts. Control without plant extracts (cells with DMSO 10:1 (v/v)) and negative control containing DMSO. MTT assay shows the reduction of MTT by mitochondrial dehydrogenase to blue formazan material, which detects the normal role of mitochondria and cell viability [10]. $20 \mu \mathrm{L}$ of PBS containing $5 \mathrm{mg} / \mathrm{mL}$ MTT was added in each well of the plate, and then the plate incubated for $3 \mathrm{hrs}$ at $37^{\circ} \mathrm{C} .20 \mu \mathrm{L}$ of MTT was added to every well, then after $3 \mathrm{hrs}$ of incubation at $37^{\circ} \mathrm{C}$, MTT withdrawn carefully from every well, and $200 \mu \mathrm{L}$ of DMSO was added. The absorbance at $570 \mathrm{~nm}$ and $630 \mathrm{~nm}$ read on a plate reader, and the difference in both readings was used for the analysis of results. The percentage of survival cells was detected by using the following formula: Survival\%=100- $((\mathrm{AC}-\mathrm{AT}) / \mathrm{AC}) \times 100)$. $\mathrm{IC}_{50}$ values were detected as the concentrations that exhibited $50 \%$ inhibition of proliferation on any tested cell line. $\mathrm{IC}_{50}$ values were detected as the average of three replicates.

\section{Statistical analysis}

The results were considered to be significant if $p<0.05$. Data are expressed as the mean \pm S.D (Standard Deviations). One way analysis of variance (ANOVA) was used for statistical analysis and Dunnett test for means difference were used to calculate cytoselectivity by comparing means of $\mathrm{IC}_{50}$ for the different plant extracts against the cancer cell lines vs. the $\mathrm{IC}_{50}$ mean of the non-cancerous cell lines.

\section{Results}

\section{In vitro cytotoxic activity of aqueous and ethanolic extracts of plants on MCF7 Cell Line}

The cytotoxic effects of $A$. chia, M. nervosa and $O$. dayi aqueous and ethanolic extracts were investigated against MCF7 cell line. MCF7 cells were incubated with various concentrations of plants extracts. After 72 $\mathrm{h}$, Cell viability was assessed using MTT assay. The $\mathrm{IC}_{50}$ was detected for all the plant extracts which have showed cytotoxic activity, Table 1. The aqueous extracts of $A$. chia, M. nervosa, and $O$. dayi, in addition to the ethanolic extracts of $A$. chia and $M$. nervosa did not exhibit a significant cytotoxic effect against MCF7 cell line. While, the ethanolic extract of $O$. dayi exhibited high cytotoxic potential against MCF7 cell line in a concentration dependent pattern, when compared with the non-treated cells (control). Results illustrate in Figure 1.

\section{In vitro cytotoxic activity of aqueous and ethanolic extracts of plants on T47D Cell Line}

The cytotoxic effects of $A$. chia, M. nervosa and $O$. dayi aqueous and ethanolic extracts were investigated against T47D cell line. T47D cells were incubated with various concentrations of plants extracts. After 72 $\mathrm{h}$, Cell viability was assessed using MTT assay. The $\mathrm{IC}_{50}$ was detected for all the plant extracts which have showed cytotoxic activity, Table 1. The aqueous extracts of $A$. chia, M. nervosa, and O. dayi, in addition to the ethanolic extracts of $M$. nervosa did not exhibit significant effect effect against T47D cell line. While, the ethanolic extract of $O$. dayi and $A$. chia exhibited high cytotoxic potential against T47D cell line in a concentration dependent pattern, when compared with the not treated cells (control). Results illustrate in Figure 2. 
Page 3 of 4

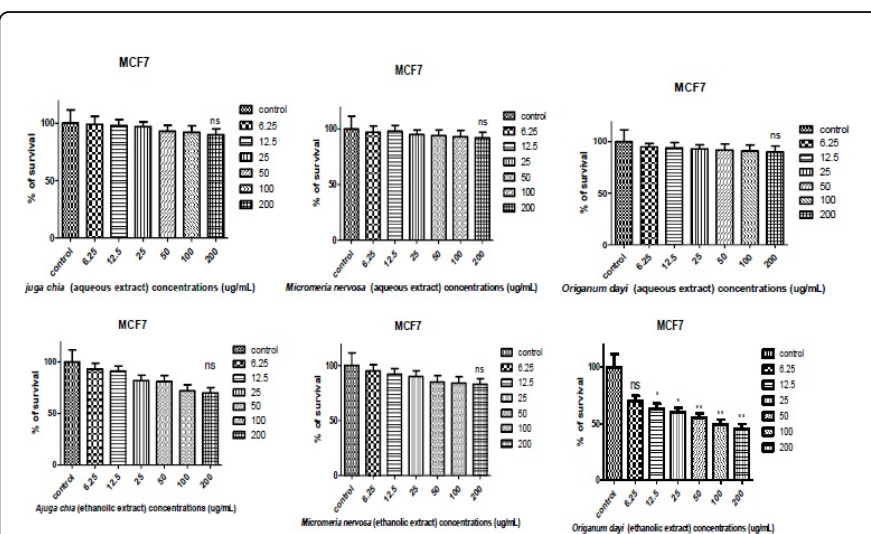

Figure 1: The cytotoxic effects of the crude aqueous and ethanoilc extracts of $A$. chia, M. nervosa and $O$. dayi on MCF7 cell lines. Cells were plated onto 96 well plates and treated with or without (control) different concentrations $(200,100,50,25,12.5$ and $6.25 \mu \mathrm{g} / \mathrm{mL})$ of the extract for $72 \mathrm{~h}$. The number of survival cells in each well was quantified by using trypan blue assay. Data are representative of at least three independent experiments. Error bars represent mean \pm SD.

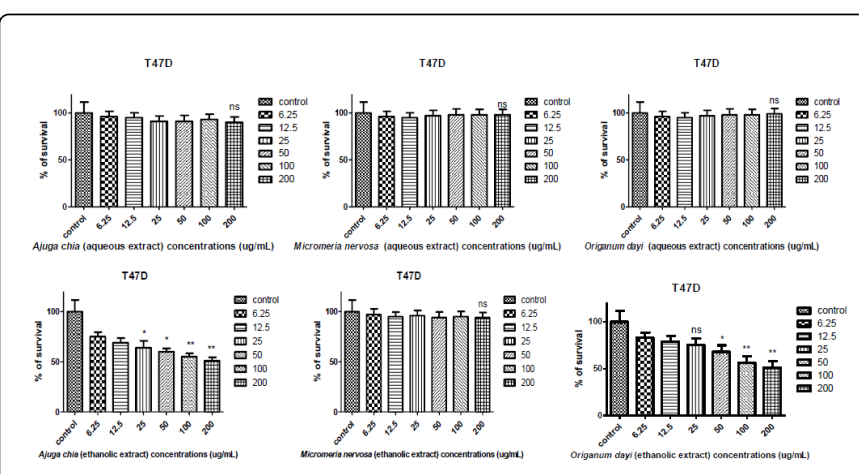

Figure 2: The cytotoxic effects of the crude aqueous and ethanolic extract of $A$. chia, $M$. nervosa and $O$. dayi on T47D cell lines. Cells were plated onto 96 well plates and treated with or without (control) different concentrations $(200,100,50,25,12.5$ and $6.25 \mu \mathrm{g} / \mathrm{mL})$ of the extract for $72 \mathrm{~h}$. The number of survival cells in each well was quantified by using trypan blue assay. Data are representative of at least three independent experiments. Error bars represent mean \pm SD.

\section{In vitro cytotoxic activity of aqueous and ethanolic extracts of plants on fibroblast cell Line}

The cytotoxic effects of $A$. chia, $M$. nervosa and $O$. dayi aqueous and ethanolic extracts were investigated against fibroblast cell line. Fibroblast cells were incubated with various concentrations of plants extracts. After $72 \mathrm{~h}$, Cell viability was assessed using MTT assay. The $\mathrm{IC}_{50}$ was detected for all the plant extracts which have showed cytotoxic activity, Table 1 . The aqueous and ethanolic extracts of $A$ chia, $M$. nervosa, and $O$. dayi did not exhibit significant cytotoxic effect against fibroblast cell line when compared with the non treated cells (control). Results illustrated in Figure 3.

\begin{tabular}{|l|l|l|l|}
\hline Cell line & A. chia (ethanolic) & O. dayi (ethanolic) & Doxorubicin \\
\hline MCF7 & NI & $99 \pm 2.9$ & $3.4 \pm 2.3$ \\
\hline T47D & $200 \pm 5.2$ & $250 \pm 4.1$ & $2.1 \pm 1.3$ \\
\hline Fibroblast & $\mathrm{NI}$ & $\mathrm{NI}$ & $0.9 \pm 1.1$ \\
\hline
\end{tabular}

Table 1: $\mathrm{IC}_{50}$ values $(\mu \mathrm{g} / \mathrm{ml})$. Measurements were recorded as the average of three replicates. The cytotoxic effect of the tested extract was detected by comparing the optical density of the treated cells versus the optical density of the control. Doxorubicin: positive control. NI: not inhibited.

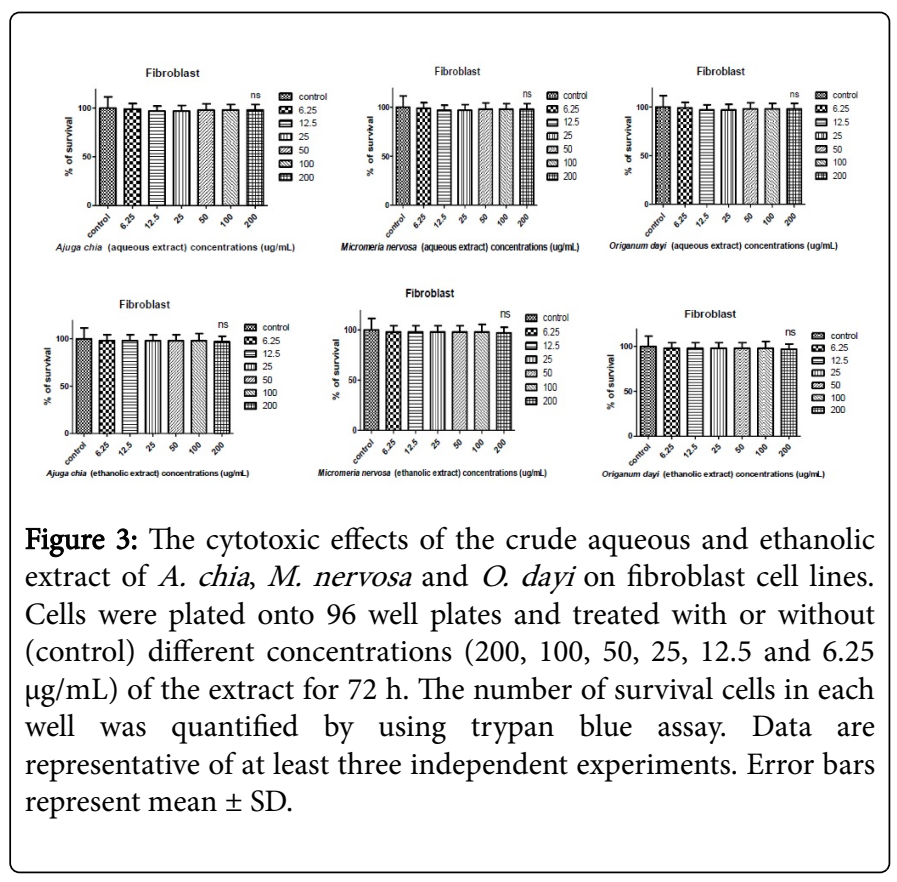

\section{Discussion}

In this study, the cytotoxicity of the crude extracts of $A$. chia, $M$. nervosa and $O$. dayi has been evaluated against MCF7 and T47D cell lines. Some of the selected plants in this study could be potential agents against breast cancer. The results showed that the most potent extracts in the present study are the extracts which plant scored the lowest $\mathrm{IC}_{50}$ in the in vitro MTT assay. Previous studies showed that $M$. nervosa has antimicrobial activities; the main antimicrobial active components are carvacrol and thymol [14]. Both extracts (aqueous and ethanolic) of $M$. nervosa were evaluated for their cytotoxic activity against T47D and MCF7 cell lines, and they did not show toxicity; the proliferation rate of cells did not differ from the untreated cells, this is probably due to the chemicals available in the aqueous and ethanolic extracts of $M$. nervosa that are not affecting the proliferation of the T47D and MCF7 cancer cell lines. There are three species of Ajuga genus in Jordan, $A$. chia used by Jordanian for wound healing [15]. The aqueous extract of A. chia did not show toxicity against the two cell lines, but the ethanolic extract of $A$. chia demonstrated cytotoxic effect against T47D cell line only, with $\mathrm{IC}_{50}=200 \pm 5.2 \mu \mathrm{g} / \mathrm{mL}$. This is could be due to the active compounds available in the ethanolic extract that exerted cytotoxicity against T47D. This is in agreement with a study that demonstrated a cytotoxic effect of Ajuga chamaecistus spp. tomentella on T47D cell lines with $\mathrm{IC}_{50} \geq 200 \mu \mathrm{g} / \mathrm{mL}$. Phytoecdysteroids and 
Citation: Yousef I, Oran S, Bustanji Y, Al-Eisawi D, Abu-Irmaileh B (2018) Cytotoxic Effect of Selected Wild Medicinal Plant Species from Jordan on Two Different Breast Cancer Cell Lines, MCF7 and T47D. Biol Med (Aligarh) 10: 443. doi:10.4172/0974-8369.1000443

Page 4 of 4

iridoid glycoside are the major components for A. chamaecistus spp. tomentella, and the cytotoxicity could be related to these compounds [11]. $O$. dayi is an aromatic plant and used as culinary plants [16] Ethanolic extract of $O$. dayi was evaluated for its cytotoxic activity against T47D and MCF7 cell lines. It showed cytotoxicity against MCF7 cell line with $\mathrm{IC}_{50}=99.4 \pm 2.9 \mu \mathrm{g} / \mathrm{mL}$ and T47D cell line with $\mathrm{IC}_{50}=250 \pm 4.1 \mu \mathrm{g} / \mathrm{mL}$. This is also in agreement with a study, which demonstrated the cytotoxic effect of the ethanolic extract of $O$. dayi on MCF7 cell line after $72 \mathrm{~h}$ of incubation, the cytotoxic mechanism that was used to induce death in these cells is a caspas-3-independent mechanism [12]. $O$. dayi has many types of volatile components such as 1,8-cineole and linalyl acetate. In addition, it has different phytochemicals like flavonoides, quercitrin and isoquercitrin. The active components in $O$. dayi that responsible for apoptosis induction are not known [13-16]. The aqueous extract of $O$. dayi in our study did not exhibit toxicity against the two aforementioned breast cancer cell lines.

\section{Conclusion}

Cytotoxic effects of the aqueous and ethanolic extracts for $A$. chia, $M$. nervosa, and $O$. dayi were assessed for the breast cancer cell lines MCF7 and T47D. The ethanolic extract of $O$. dayi demonstrated a pronounced cytotoxicity against MCF7 and T47D. The ethanoilc extract of $A$. chia exhibited cytotoxicity against T47D while $M$. nervosa did not show any toxicity against the two breast cancer cell lines. $O$. dayi is suggesting a promising plant against breast cancer.

\section{Acknowledgement}

The authors are appreciating the financial support of the Deanship of Scientific Research, University of Jordan for the financial support. The authers also are indebted to School of Pharmacy, Hamdi Mango center and the Department of Biological Sciences for the space and scientific facilities offered to the authors during the period (2016-2018).

\section{References}

1. Petrovska BB (2012) Historical review of medicinal plants usage. Pharmacogn Rev 6: 1-5.

2. Oran SA, Al-Eisawi DM (1998) Check-list of medicinal plants in Jordan. Dirasat 25: 84-112.
3. Jain K (1985) Medicinal Plants of India (5thedn). Raj Bandhu Industrial Company, 1-4.

4. Mossa JS, Al-Yahya MA, Al-Meshal IA (1987) Medicinal Plants of Saudi Arabia, Saudi Arabia: King Saud University.

5. Oran S (2014) The status of medicinal plants in Jordan. Journal of Agriculture Science and Technology 4: 461-457.

6. Oran S, Al-Eisawi D (2015) Ethnobotanical survey of the medicinal plants in the central mountains (North-South) in Jordan. J Bio Env Sci 6: 381-400.

7. Oran SA (2015) Flora of Bader Al-Jadida county, western high mountain of Amman city/Jordan. International Journal of Herbal Medicine 3: 49-59.

8. Bustanji Y, Al-Douri N, Issa AS, Assaf A, Aburjai T, et al. (2012) Cytotoxic effect of Mercurialis annua L. methanolic extract on six human solid cancer cell lines. Scientific Research and Essays 7: 3218-3222.

9. Arkoob K, Al-Nsour M, Al-Nemry O, Al-Hajawi B (2010) Epidemiology of breast cancer in women in Jordan: patient characteristics and survival analysis/Épidémiologie du cancer du sein chez les femmes: caractéristiques des patients et analyse du taux de survie en Jordanie. East Mediterr Health J 16: 1032.

10. Lau CB, Shu Ho, Kim CY, Leung CF, Fung KN, et al. (2004) Cytotoxic activities of Coriolus versicolor (Yunzhi) extract on human leukemia and lymphoma cells by induction of apoptosis. Life Sci 75: 797-808.

11. Sadati N, Ostad SN, Karimian Z, Ardekani MS, Akbarzadeh T, et al. (2012) Phytochemical study and in vitro cytotoxic effect of Ajuga chamaecistus ssp. tomentella. Asian Journal of Chemistry 24: 2871-2874.

12. Solowey E, Lichtenstein M, Sallon S, Paavilainen H, Solowey E, et al. (2014) Evaluating medicinal plants for anticancer activity. ScientificWorldJournal.

13. Bhatia D, Mandal A, Nevo E, Bishayee A (2015) Apoptosis-inducing effects of extracts from desert plants in HepG2 human hepatocarcinoma cells. Asian Pac J Trop Biomed 5: 87-92.

14. Ali-Shtayeh MS, Al-Nuri MA, Yaghmour RM, Faidi YR (1997) Antimicrobial activity of Micromeria nervosa from the Palestinian area. J Ethnopharmacol 58: 143-147.

15. Khalil EA, Afifi FU, Al-Hussaini M (2007) Evaluation of the wound healing effect of some Jordanian traditional medicinal plants formulated in Pluronic F127 using mice (Mus musculus). J Ethnopharmacol 109: 104-112.

16. Sallon S, Solowey E, Cohen Y, Korchinsky R, Egli M, et al. (2008) Germination, genetics, and growth of an ancient date seed. Science 320: 1464. 